Vol. 1, No. 2, Desember 2020

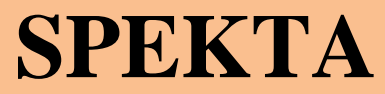

Jurnal Pengabdian Kepada Masyarakat : Teknologi dan Aplikasi

Journal homepage :

http://journal2.uad.ac.id/index.php/spekta

\title{
PELATIHAN DAN PENDAMPINGAN PENGOLAHAN SAMPAH MENJADI PRODUK BERNILAI EKONOMI PADA BANK SAMPAH BERSIH BERSAMA KARANGANOM, SITIMULYO, PIYUNGAN, BANTUL
}

\section{Tri Budiyanto*, Reni Dwi Astuti, Annie Purwani}

Program Studi Teknik Industri, Universitas Ahmad Dahlan, Bantul, Daerah Istimewa Yogyakarta, Indonesia

\section{INFO ARTIKEL \\ Diterima: 4 November, 2020 \\ Direvisi: 7 November, 2020 \\ Disetujui: 10 November, 2020}

Keywords:

Waste Bank;

Paper and Plastic Waste;

Coffee Sachet Bags;

\begin{abstract}
The "Bersih Bersama" Waste Bank located in Karanganom, Sitimulyo, Piyungan, Bantul, Yogyakarta Special Region was a waste bank that still exists to manage waste from the local community. The problems faced include that management ware still limited to receiving from customers, then collected and handed over to collectors. The customer was not always doing the sorting process, so the managers have to sort and even have to clean it first. In addition, the level of community awareness to manage waste is still lacking. The purpose of community service was to provide additional skills to members of the waste bank to convert used goods that were originally only sorted and sold, converted into products that have use value and sale value. Community service activities were carried out by organizing training and assistance in making coffee sachet bags using waste paper and coffee sachets (plastic) directly to the community. This training was carried out in 2 stages, namely on September 20 for stage 1 and October 10, 2020 for stage 2. The results of the implementation of community service were increased knowledge about the use of paper and plastic waste, the ability to make new products in the form of coffee sachet bags with attractive motifs that have value. added. A positive impact can be seen from the increased knowledge and understanding of waste bank members in the use of paper and plastic waste into useful and economic goods. In addition, the Karanganom Sitimulyo community can contribute to reducing plastic waste in their environment.
\end{abstract}

\footnotetext{
* Corresponding author.

E-mail address: tribdy@yahoo.com

https://doi.org/10.12928/spekta.v1i2.3044
} 


\section{PENDAHULUAN}

Permasalahan sampah selalu menjadi sorotan baik dikota maupun di daerah atau desa. Kondisi ini juga dipicu dengan bertambahnya jumlah penduduk. Kota Yogyakarta diperkirakan bisa menghasilkan sampah sebanyak 300 ton per hari. Menurut pernyataan Dinas Lingkungan Hidup (DLH) Kota Yogyakarta, satu orang penduduk dapat menghasilkan 0,7 kilogram per hari di wilayah setempat. (Tribunjogja, 2019), hal ini mendorong untuk melakukan pengelolah sampah secara tepat dan benar. Pengelolaan sampah yang tidak tepat dapat menimbulkan dampak risiko penyakit akan meningkat (Sari, 2016), menimbulkan bau menyengat, membuat kumuh perkampungan, mencemari lingkungan termasuk selokan dan sungai.

Di sisi lain keberadaan sampah ternyata bisa menjadi sumber daya yang dapat berkontribusi menambah penghasilan bagi yang mampu mengolahnya menjadi produk lain bernilai jual. Berdasarkan Undang-Undang No. 18 Tahun 2008 tentang Pengelolaan Sampah, Bab 2 Pasal 4 dikatakan bahwa pengelolaan sampah bertujuan untuk meningkatkan kesehatan masyarakat dan kualitas lingkungan serta menjadikan sampah sebagai sumber daya. Di era sekarang muncul pola baru yang berkembang di masyarakat, sampah sudah dipandang sebagai sumber daya yang bernilai ekonomi bagi pelaku pengelolaan sampah (Indartik dkk., 2018) dan juga masyarakat yang menjadi anggotanya. Alasan ini yang memicu munculnya berbagai bank sampah di beberapa tempat baik di desa, pinggiran kota bahkan di kota. Keberadaan bank sampah sangat mendukung program pemerintah dalam penangganan sampah yang lebih ramah dan berpotensi memberikan keuntungan (Budiyanto, 2020).

Bank Sampah "Bersih Bersama" yang berlokasi di Karang Anom, Sitimulyo, Piyungan, Bantul, Daerah Istimewa Yogyakarta merupakan salah satu contoh bank sampah yang sampai sekarang masih eksis mengelola sampah dari masyarakat setempat. Pengelolaah bank ini dapat bertahan lama dan terus meningkat dari sejak didirikan oleh Pemerintah Kabupaten Bantul sampai sekarang karena dikelola team work pengurus yang solid. Sampai sekarang jumlah anggota bank samoah ini sudah mencapai 70 orang. Secara riil dengan implementasi program bank sampah dikelola dengan baik, berpotensi menambah pendapatan keluarga sekaligus sebagai upaya penyelamatan lingkungan masyarakat dalam manajemen operasi bank dan investasi dalam bentuk tabungan (Dewanti dkk., 2020). Pengelolaan bank ini masih sebatas penerimaan dari nasabah selanjutnya dikumpulkan dan diserahkan kepada pengepul. Keuntungan penjualan didistribusikan dengan cara bagi hasil yang transparan. Proses pemilahan tidak selalu dilakukan oleh nasabah, sehingga para pengelola harus menyempatkan memilah dan bahkan membersihkan dulu terutama yang ada cairannya. Selain itu tingkat kesadaran masyarakat untuk mengelola sampah masih kurang. Sampah yang dikelola berupa sampah kering seperti kardus, kertas, bungkus plastik, botol minuman plastik.

Sampah jenis kertas atau plastik belum dikelola secara baik untuk menjadi produk lain yang mempunyai nilai tambah. Sampah-sampah plastik maupun sampah kertas akan lebih bernilai jika didaur ulang menjadi sebuah produk (Hartono dan Untari, 2018). Setidaknya ada dua manfaat mengelola sampah yaitu dapat mengurangi tumpukan sampah dan dapat mendatangkan pendapatan tambahan (Astuti dkk., 2019). Secara umum pengolahan sampah, khususnya sampah plastik masih belum banyak dilakukan. Pengolahan daur ulang plastik menjadi produk lain bernilai ekonomis di Indonesia belum tertertangani secara baik, masih sekitar $90 \%$ dari keseluruhan produksi sampah (Arvianti dkk., 2016). Berbagai olahan dari bahan sampah plastik yang dapat menilai tambah seperti dompet, tas belanja, tempat pensil dan lain sebagainya sudah mulai bermunculan. 
Pengelolaan sampah seharusnya dilaksanakan berdasarkan pada beberapa asas termasuk asas manfaat dan asas nilai ekonomi (Mayangkara, 2016).

Untuk memberdayakan anggota Bank Sampah Bersih Bersama yang kebanyakan beranggotakan ibu-ibu perlu dilakukan pengabdian dalam bentuk kegiatan pelatihan dan pendampingan pembuatan produk dari barang bekas seperti sampah kertas dan plastik. Tujuan pelatihan untuk memberi ketrampilan tambahan ibu-ibu anggota bank sampah dalam mengubah barang bekas yang semula hanya dipilah dan dijual, dirubah menjadi produk lain yang mempunyai dinlai guna dan nilai jual. Pengolahaan sampah menjadi sesuatu yang bernilai dan berkontribusi pada perekonomian masyarakat dapat dilakukan melalui peningkatan kemampuan masyarakat dalam mengelola sampah dengan pelatihan (Silalahi, 2017). Dengan memahami dan mengikuti pelatihan pemanfaatan limbah sampah menjadi produk yang bernilai tambah diharapkan ibu-ibu anggota bank sampah mampu membuat produk secara mandiri dan mengembangkan sesuai kreasi masingmasing

\section{METODE PELAKSANAAN}

Kegiatan pengabdian kepada masyarakat dilakukan dengan menerapkan metode pelatihan dan pendampingan secara langsung di lapangan. Mitra sasaran yang digunakan adalah anggota Bank Sampah Bersih Bersama berlokasi di Karang Anom, Sitimulyo, Piyungan, Bantul, Daerah Istimewa Yogyakarta. Subjek sasaran berjumlah 12 orang yang terdiri dari ibu-ibu, dan pemuda. Kegiatan pelatihan dan pendampingan dilakukan 2 tahap, diawali dengan persiapan, pelaksanaan meliputi pelatihan dan pendampingan dilanjutkan evaluasi. Kegiatan diselenggarakan pada tanggal 29 September dan 14 Oktober 2020. Kegiatan pelatihan diberikan oleh traniner yang berpengalaman dalam pembuatan produk dengan bahan limbah sampah plastik dan kertas. Kegiatan pendampingan melibatkan 2 mahasiswa. Kegiatan pelatihan diselenggarakan di tempat pengolahan sampah Bersih Bersama

\section{HASIL DAN PEMBAHASAN}

Kegiatan pelatihan mengolah sampah kertas dan plastik (sachet) bekas menjadi produk tas dilakukan 2 tahap. Tahap pertama dilakukan dengan menggunakan bahan sampah kertas bekas sebagai latihan dan pembiasaan. Tahap kedua menggunakan sachet kopi, setelah para peserta mampu dan menguasai tahap pertama. Penyiapan bahan dilakukan dengan pemilihan bahan dari kertas bekas dan sachet kopi. Kedua bahan tersebut dipotong sesuai ukuran yang dikehendaki, untuk bahan sachet kopi dicuci sebelum dipotong. Selanjutnya membuat lipatan kertas dan sachet yang sudah dipilih dengan ukuran lebar $2,5 \mathrm{~cm}$ dan panjang $20 \mathrm{~cm}$ dan jumlahnya lebih banyak dari kebutuhan riil, fungsinya untuk cadangan kalau ada lipatan yang rusak saat menganyam. Pekerjaan penyiapan bahan ini dilakukan di rumah masing-masing peserta. Hal ini dilakukan dengan tujuan untuk mempermudah dan memperlancar selama pelaksanaan pelatihan baik untuk tahap pertama dan kedua. Selain itu peserta secara langsung mempraktekan pengurangan limbah kertas dan sachet kopi rumah tangga.

Pelatihan tahap pertama diawali penyampaian materi dengan cara penjelasan secara singkat, dilanjutkan dengan praktek secara langsung membuat anyaman dari bahan kertas yang sudah dipersiapkan sebelumnya. Cara seperti ini ternyata cukup menarik dan mudah dipahami oleh peserta. Dalam pelatihan peserta dibagi kedalam 4 kelompok, masing-masing kelompok terdiri dari 3 orang. Dalam pelatihan peserta langsung mempraktekkan bersama arahan trainer menganyam bahan yang sudah 
Vol. 1, No. 2, Desember 2020

disiapkan sesuai alur yang sudah ditentukan. Tujuan pelatihan ini untuk memberi pemahaman peserta, sehingga mempermudah saat melakukan praktek setelah pelatiahan. Dalam kegiatan pelatihan, peserta diberi waktu yang cukup untuk bertanya, berdiskusi dan meminta arahan kalau terjadi kesalahan waktu menganyam. Langkah berikutnya menjahit anyaman dengan benang untuk memperkuat hasil anyaman dan untuk proses menyatukan anyaman bagian bawah. Proses anyaman dianggap selesai kalau produknya sudah berbentuk tas dan kuat pada anyamannya.

Pelatihan tahap kedua dilakukan sama seperti pada langkah-langkah tahap pertama. Pada tahap ini pelatihan dilakukan dengan menggunakan bahan sachet kopi. Peserta harus lebih cermat dan memahami posisi gambar yang menonjol pada sachet kopi pada saat dianyam, sehingga nantinya dapat dihasilkan tas sachet kopi dengan motif gambar yang seragam dan serasi pada tampak luar anyaman. Proses anyaman dianggap selesai bila produknya sudah berbentuk tas dan kuat pada anyamannya serta motif gambarnya sudah terpola dengan baik.

Tahapan pembuatan tas sachet kopi dapat dilihat pada Gambar 1, pelaksanaan pelatihan pada Gambar 2 dan kegiatan pendampingan pada Gambar 3. Ukuran keberhasilan dalam pelatihan ini dievaluasi dari kemampuan perserta dalam membuat produk tas saset kopi dengan kulaitas baik. Hasil evaluasi menunjukkan kemampuan peserta dalam pembuatan produk tas sachet kopi dapat dinyatakan 100\%. Hal ini menginformasikan bahwa semua peserta setelah mengikuti pelatihan dapat melakukan sesuai materi yang diberikan. Penilaian pada kualitas produk, hanya 3 kelompok atau $75 \%$ yang berhasil membuat tas sachet kopi yang sesuai ketentuan. Kualitas ini dapat dilihat dari tingkat kekuatan dan motif gambar pada anyaman tas plastik yang terbentuk.

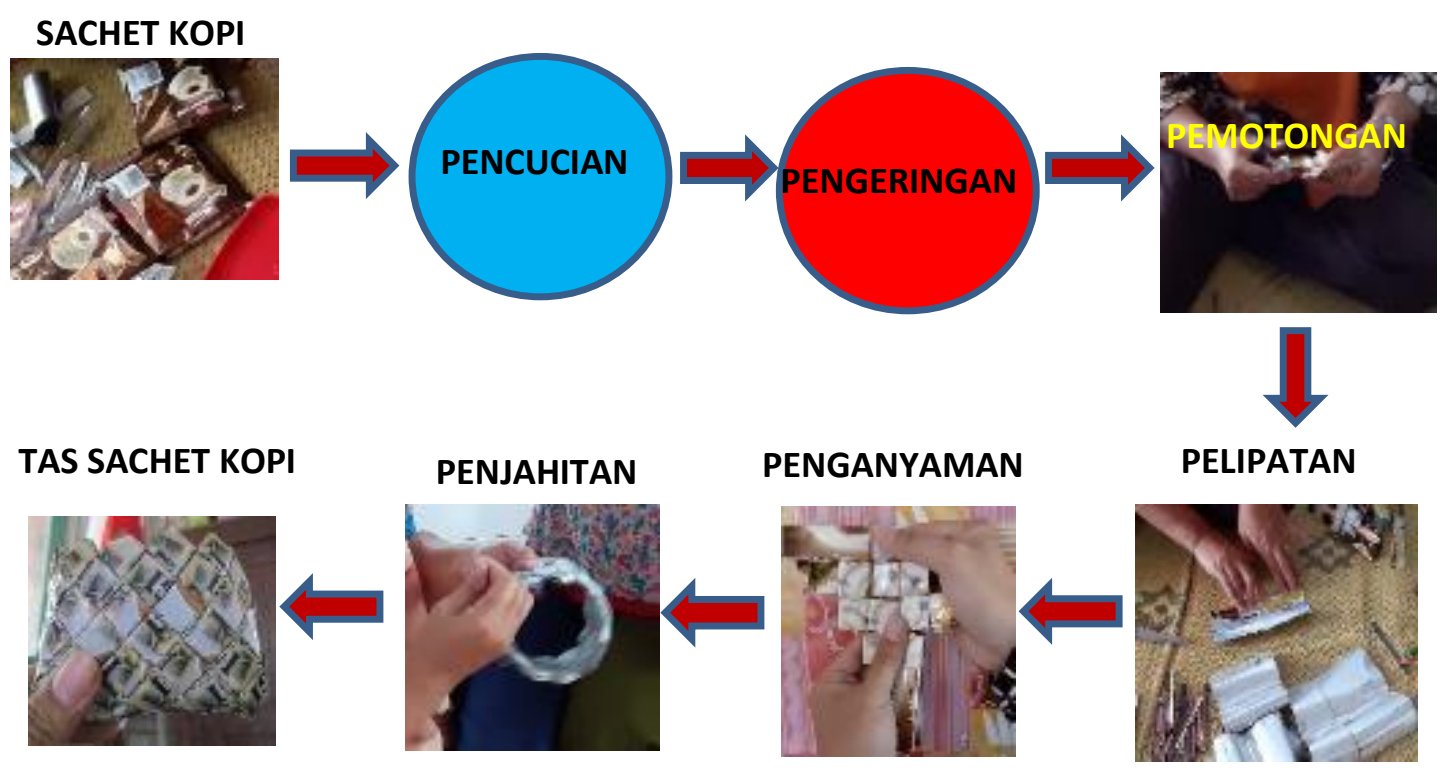

Gambar 1 Tahapan Proses Pembuatan Tas Saset Kopi 
Vol. 1, No. 2, Desember 2020

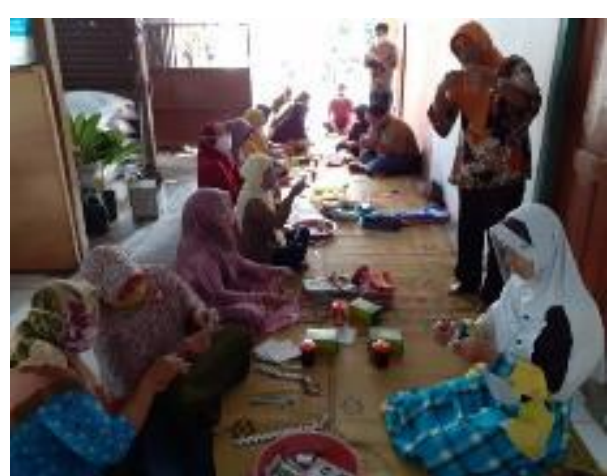

Gambar 2 Kegiatan Pelatihan Pembuatan Tas Sachet Kopi

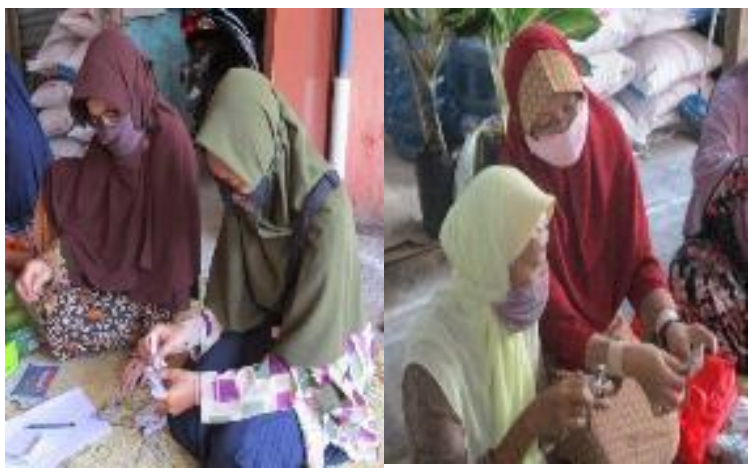

Gambar 3 Kegiatan Pendampingan Pembuatan Tas Sachet Kopi

\section{KESIMPULAN}

Kegiatan pelatihan dan pendampingan pemanfaatan sampah kertas dan sachet kopi menjadi produk tas sachet kopi bagi anggota bank sampah Bersih Bersama di Karang Anom, Sitimulyo, Piyungan, Bantul, Daerah Istimewa Yogyakarta dapat diselenggarakan dengan baik dan lancar. Melalui pengabdian masyarakat dengan kegiatan pelatihan dan pendampingan yang diberikan mampu menambah pengetahuan baru tentang pemanfaatan sampah kertas dan plastik dalam membuat tas sachet kopi secara mandiri.

\section{UCAPAN TERIMA KASIH}

Terimakasih kepada LPPM Universitas Ahmad Dahlan, Tim PPM, mahasiswa, pengurus dan anggota Bank Sampah Bersih Bersama di Karang Anom, Sitimulyo, Piyungan, Bantul, Daerah Istimewa Yogyakarta atas semua bantuan dan sudah bersedia bekerjasama demi terlaksananya program ini

\section{DAFTAR PUSTAKA}

Arvianti, E. Y., Suroto K. S., Situmeang T. 2016. Teknologi Daur Ulang Kertas Koran Menjadi Kerajinan Tangan Bernilai Jual Tinggi Dan Analisa Kelayakannya. (Studi Kasus Di Kelompok Ibu Rumah Tangga Sekarwangi Malang). Jurnal Buana Sains. Vol 16 No. 2: 129-136.

Astuyi I. P., Buntoro G. A., Ariyadi D., 2019. Pelatihan Pemanfaatan Barang Bekas untuk Pembuatan Buket Bunga dan Cara Pemasarannya. WARTA LPM, Vol. 22, No. 1 : 6-10. p ISSN: 1410-9344, e ISSN: 2549-5631

Budiyanto, T. (2020) "Strategi Pemasaran Usaha Kecil Menengah Pada Ibu-Ibu Aisyiah Muhammadiyah Bali," SPEKTA (Jurnal Pengabdian Kepada Masyarakat: Teknologi dan Aplikasi), 1(1), p. 17. doi: 10.12928/spekta.v1i1.2649.

Dewanti M. , Eko Priyo Purnomo E. P., , Lubna Salsabila L., 2020. Analisa Efektifitas Bank Sampah Sebagai Alternatif Pengelolaan Sampah Dalam Mencapai Smart City Di Kabupaten Kulon Progo. Jurnal Ilmu Administrasi Publik. Volume: 5 (1): p. 21 - 29. DOI: Prefix 10.26905. ISSN: 2541-2515(p), 2541-2035(e) . http://jurnal.unmer.ac.id/index.php/jkpp

Mayangkara A. P., 2016. Evaluasi Kebijakan Pengelolaan Sampah Di Tpa Gunung Panggung Kabupaten Tuban, Jurnal Penelitian Administrasi Publik. Vol. 2 No. 2, hal. 427 - 444. e-ISSN: 2460-1586. 
Haryono N. A. dan Untari N. 2018. Pelatihan Produk Daur Ulang Sampah Plastik. Jurnal Pengabdian Masyarakat. Volume 2, Nomor 1. Hal. 27-39. p-ISSN : 2548-8805 eISSN : 2548-8813.

Indartik, Suryandari E. Y., Djaenudin D., Pribadi M. A., 2018. Penanganan Sampah Rumah Tangga di Kota Bandung: Nilai Tambah Dan Potensi Ekonomi. Jurnal Penelitian Sosial dan Ekonomi Kehutanan Vol. 15 No.3, Hal. 195-211. doi: http://dx.doi.org/10.20886/jpsek.2018.15.3.195-211. p-ISSN 1979-6013. e-ISSN 2502-4221

Peraturan Pemerintah Republik Indonesia Nomor 81 Tahun 2012 Tentang Pengelolaan Sampah Rumah Tangga Dan Sampah Sejenis Sampah Rumah Tangga. http://extwprlegs1.fao.org/docs/pdf/ins84136bah.pdf. 1-11-2020

Sari P. N., 2016. Analisis Pengelolaan Sampah Padat Di Kecamatan Banuhampu Kabupaten Agam. Jurnal Kesehatan Masyarakat Andalas. Vol. 10, No. 2, Hal. 157165

Silalahi B., 2017. Pengaruh Pengetahuan Tentang Sampah Dan Ketersediaan Sarana Prasarana Terhadap Perilaku Ibu Membuang Sampah Yang Berpotensi Bencana Banjir Di Daerah Aliran Sungai Deli Kota Medan. Jurnal Ilmiah Keperawatan $\begin{array}{lllll}\text { Imelda } & \text { Vol. } & 3, & \text { No. } & \text { 1, }\end{array}$ http://jurnal.uimedan.ac.id/index.php/JURNALKEPERAWATAN. e-ISSN 2597-7172, p-ISSN 2442-8108

Tribunjogja.com. Jogja (2019). https://jogja.tribunnews.com/2019/10/10/kota-yogyahasilkan-300-ton-sampah-tiap-hari , diunduh 1-11-2020 